\title{
Karl Polanyi and discussions on a renewed socialism
}

\author{
Michael Brie (brie@rosalux.de) \\ Rosa Luxemburg Foundation, Germany
}

The paper reconstructs Karl Polanyi's search process for a socialist answer to the crisis of capitalist civilization in the first half of the 20th century. Polanyi focused on the question of how the conditions for responsible freedom can be realized under the conditions of a complex society. For Polanyi, this only seemed possible if a new Great Transformation of society were to take place, leaving the capitalist market society behind. Polanyi concentrated on three paths: (1) the diminishing of the commodity character of natural resources, labor and money; (2) the comprehensive democratization of economic decisions on the basis of deglobalization and intraregional cooperation; and (3) the institutional safeguarding of individual freedom at the expense of economic efficiency.

Keywords: Gemeinschaft and Gesellschaft, Transformation of Capitalism, Neo-Socialism

\section{Gemeinschaft and Gesellschaft - the complexity of society}

The last chapter of Karl Polanyi's famous work The Great Transformation was titled Freedom in a Complex Society. This title itself expresses one of the most fundamental contradictions at the heart of the socialist tradition and in Polanyi's thinking itself - the contradiction between Gemeinschaft and Gesellschaft. Socialism in general and Polanyi's understanding of socialism in particular are visions of an "association, in which the free development of each is the condition for the free development of all" (Marx \& Engels, 1976, 506). From their early beginnings in the aftermath of the Great French Revolution, socialism and communism challenged the emerging modern capitalist societies, demanding that freedom should not be a privilege but accessible to the last favored classes and groups. In the words of one of the most far sighted critiques of socialism, Lorenz von Stein, communism expresses the scandal that in the freest society humankind has ever seen new forms of unfreedom have emerged and one class is exploiting and suppressing the other (Stein, $1959,8)$. Society is unable to govern its own reproduction as a society of freedom.

The classical communist solution to this scandal is the transformation of complex capitalist societies into a community of communities based on the common property of the producers (in the broadest sense) or of a Gesellschaft with complex institutions of intermediation to a Gemeinschaft or association of individuals bound by common property and direct collective self-government. Everybody should become a collective owner and producer in one and the same person. All social relations should become interrelations of persons, directly regulated by rational and purposeful collective action. No hidden hand should steer the development and no private property should withstand solidarity. Money, law, and state would vanish after a shorter or longer transitional period. Revolutionary communism in the tradition of François Noël Babeuf tried to implement this type of society by taking over the state apparatus. Evolutionary communism in the tradition of Robert Owen proposed 
and experimented with building-up concrete communities of New Harmony. The result would be the same - rebuilding societies as communities. Karl Marx resumed this position in his main work, Capital, as follows: "Let us now picture to ourselves ... a community of free individuals, carrying on their work with the means of production in common, in which the labour power of all the different individuals is consciously applied as the combined labour power of the community. [...] The social relations of the individual producers, with regard both to their labour and to its products, are in this case perfectly simple and intelligible, and that with regard not only to production but also to distribution" (Marx, 1996, $89 \mathrm{f.)}$.

In 1887 Ferdinand Tönnies published his most important work Gemeinschaft und Gesellschaft with the not so well-known subtitle "An Essay on Communism and Socialism as Empirical Cultural Forms" (in 1912 the subtitle was replaced by "'Fundamental Concepts in Pure Sociology"). In this work he introduced the difference between two analytically opposed types of social relations. ${ }^{1}$ Beside Henry Maine's works on ancient societies and Otto von Gierke's on cooperatives, Tönnies refers in his foreword of 1887 to Karl Marx as "the strangest and deepest social philosopher" (Tönnies, 1887, XXVIII). Tönnies defines his dichotomist terms in the following way: "All kinds of social co-existence that are familiar, comfortable and exclusive are to be understood as belonging to Gemeinschaft. Gesellschaft means life in the public sphere, in the outside world. In Gemeinschaft we are united from the moment of our birth with our own folk for better or for worse. We go out into Gesellschaft as if into a foreign land." (Tönnies, 2001, 18). It should be noted that for Tönnies socialism is result of a tendency to bring Vergesellschaftung under social control which - becoming total and thus transforming society into a Gemeinschaft again - would be selfdefeating. ${ }^{2}$ This position had an impact on Karl Polanyi, as we will see (see also Dale, 2010, $34 \mathrm{ff}$.$) .$

Karl Polanyi's understanding of socialism seems to be fed and enriched by at least three "sources," which made him doubt this identification of socialism with Gemeinschaft. Firstly it was shaped by his permanent and lasting reflection of very different currents of socialism and critiques of socialism and communism (see for an overview Cangiani, Polanyi-Levitt \& Thomasberger, 2005). Secondly it was shaped by his work as an outstanding analyst of international political and economical affairs working for the Österreichischer Volkswirt. His analysis of the crisis-ridden period after WWI and during the late 1920s and 1930s were a rich source of deep understanding of the relations between economics, politics, and the values of complex capitalist societies. More and more he became aware of the problems faced by committed left governments, labour unions, and left parties of combining an orientation toward social justice, individual freedom, and economic efficiency (Polanyi,

\footnotetext{
1 Interestingly enough the English translation of the title of Tönnies' work was changed several times: In 1940 Tönnies' work was translated by Charles P. Loomis and published under the title Fundamental Concepts of Sociology (Gemeinschaft und Gesellschaft), in 1955 the same work was published as Community and Association and in 1957 as Community and Society. The most current translation of the book title by Jose Harris and Margaret Hollis is Community and Civil Society. Frequently in the translation Gesellschaft is not translated at all.

2 In the concluding remarks of his work. Ferdinand Tönnies writes, "The whole movement, from its first appearance and through all its subsequent stages, can also be understood as a transition from original, simple, family-based communism, and the small-town individualism that stems from it - through to an absolutely detached cosmopolitan and universalist individualism and to the state-based and international socialism generated by it. Socialism is already latent in the very concept of Gesellschaft, although it begins only in the form of practical links between all the forces of capitalism and the state, which is specifically employed by them to maintain and advance the commercial order. Gradually, however, it turns into attempts to impose centralised control on business and on labour itself through the mechanism of the state - which, if they were to succeed, would put an end to the whole of competitive market society and its civilisation.(Tönnies, 2001, 260) The East-German philosopher Peter Ruben has developed a deep analysis of state socialism and the failure to impose Gemeinschaft as the main principle of Vergesellschaftung on complex societies (Ruben, 1995, 1998; see also Crome, 2006).
} 
2002a, 2003). A third source became his ever increasing interest in precapitalist societies and their relation to market and non-market forms of regulation (see Polanyi, 1957, 1966). Based on the insights of these three currents of his work, Polanyi started to doubt the orthodox assumption that socialism will be a Gesellschaft reduced to Gemeinschaft. In The Great Transformation this assumption was finally no longer held at all - freedom should be realized in a complex society never reducible to Gemeinschaft and dealing with very different institutional forms always confronted with the problem of objectivations and relative independence (Verselbständigung) and alienation (Entfremdung) but having the horizon a community of free individuals acting together in solidarity.

In his debate with Ludwig von Mises, Karl Polanyi ${ }^{3}$ bases his argument on socialism as a Gemeinschaft of individuals organized in functionally differentiated organizations (see Bockman, 2013). In his work Gemeinwirtschaft, Mises argued that a economy based on common property is not feasible (or is at least less efficient than a market economy) due to the fact that it would be impossible to establish prices for the factors of production making an efficient allocation of these factors impossible and neglecting opportunity costs (Mises 1932). In line with concepts developed by G.D.H. Cole (1920) and the Austrian School of Marxism (Bauer, 1976), Karl Polanyi tried to prove that even on the basis of common property and united in one Gemeinschaft different actors can emerge - the collective producers (Produktionsverband), the collective consumers (Konsumgenossenschaften), and the communities (Kommune). In this "functional socialism" (Polanyi, 2005b, 72) these associations are "functional representations" of one and the same individuals in different roles (Polanyi, 2005b, 97). This functional socialism is clearly distinguished from any type of a centralized command economy based on the assumption of a mono-subject.

In the second half of the 1920s, the focus of Polanyi's search for socialist alternatives shifted from the problem of accountancy to the problem of freedom. This was in line with his earlier critique of corporatism and bureaucratization in the works of the first decade of the $20^{\text {th }}$ century (see Cangiani, Polanyi-Levitt \& Thomasberger, 2005, $21 \mathrm{f}$.). His lecture "On Freedom" in 1927 is centered on the question of how individual freedom can be possible in a complex society. In the liberal market societies, nobody has control over the results of his or her actions, and the consequences of free personal decisions are left to the "hereafter of the market": "The idea of being responsible for our personal share in the life of 'others', that is, in social realities, and incorporating it into the realm of freedom is not possible in the bourgeois world. But it is just as impossible to abjure and thus to voluntarily limit our responsibility and thus our freedom. The bourgeois world's idea of freedom and responsibility points beyond the boundaries of this world" (Polanyi, 2005c, 146).

In this lecture, Polanyi on the one hand still referred to socialism as a society which is an assembly of direct personal relations, as a cooperation of individuals, "when the social relations of people to each other become clear and transparent, as they are in a family or in a communistic community" (Polanyi, 2005c, 150). On the other hand, he reflects on the problem that even in the most advanced socialist society forms of "objectivations" will remain. The state, markets, and law will not vanish but will become much less "entfremdet" from the concrete actions of concrete individuals. He resumes his position as follows: "... the idea of functional democracy, of functional representation ... leads to robbing the political objectification state power of its reified character to an extent that is up to now unimaginable and approaching the direct expression of the impulses towards law of the individual. A complete cancellation of the objectification law naturally does not occur here. It is not even thinkable. The congealed will, which we call law, remains forever as a wall between past impulses to law and the fluid impulses to law which are at work today. However, in a functional democracy this wall will be infinitely thin and completely

${ }^{3}$ At this point the author is not able to include Karl Polanyi's intellectual life in Hungary until 1914. 
transparent - which is the most that our fantasy with regard to social freedom currently lets us imagine" (Polanyi, 2005c, 162).

This discussion of the role of "objectivations" continues in Karl Polanyi's works during his stay in Great Britain while he was involved in discussions in left Christian groups and different forms of workers' education. I will restrict myself here to the distinction he made between society and community (Gesellschaft and Gemeinschaft). The late 1930s, in other words the years immediately preceding the writing of The Great Transformation, were a time of intensive teaching activity for Polanyi, first in the circle of the Christian Left Group ${ }^{4}$ and then in the Workers Educational Association, whose president was R. H. Tawney. ${ }^{5}$ This framework of teaching and discussion represented the decisive space for his thinking before he wrote his main work. This is where the narrative of the book arose and took final shape. ${ }^{6}$ Here he came into contact with England's socialist thought, above all with that of Robert Owen. Here he formulated his specific view of the distinction between society and community, which also underpins The Great Transformation. This is also where he developed his position on the limits of Christian attempts to lead society back to community. From here on "recognition of the reality of society," of the complexity of society, became for him an indispensable condition of every emancipatory-solidarity politics. He said both positively and critically: "The Christian axiom about the essence of society is of the utmost boldness and paradoxy. It can be put in the simple phrase that society is a personal relation of individuals. Now, to regard society thus means to disregard altogether the share of institutional life and of other impersonal forces in social existence. In a sense it is the complete denial of the objective existence of society. [...] Two negative assertions seem to follow from this position. 1. Society as such, as an aggregate of functional institutions ... is no concern of Christianity. His concern is with the individual in community, not with society. 2. Neither is history as such his concern" (Polanyi, n.d., 1-3). In view of the big catastrophes, however, this double "indifference" is no longer acceptable: "if the claims of

\footnotetext{
${ }^{4}$ In this context he published Christianity and the Social Revolution (Lewis, Polanyi \& Kitchin, 1935) together with John Macmurray, Joseph Needham, and others. Through this he could have also been influenced by Macmurray's positions, who saw community and society as necessary poles of human-social existence, neither of which can be dissolved into each other: "The members of a community are in communion with one another, and their association is a fellowship. And since such an association exhibits the form of the personal in its fully positive personal character, it will necessarily contain within it and be constituted by its own negative, which is society. Every community is a society; but not every society is a community" (Macmurray, 1961, 146).

${ }^{5}$ Repeatedly, Polanyi comes back to the motif of the "acquisitive society," the subject of Tawney's first influential book (Tawney, 1920). Tawney had criticized an ideology that derived the fulfilment of societal functions purely from "free," egotistical action, and he contrasted this with the vision of a society that rests on the connection between personal responsibility and social functions: "A society which aimed at making the acquisition of wealth contingent upon the discharge of social obligations, which sought to proportion remuneration to service and denied it to those by whom no service was performed, which inquired first not what men possess but what they can make or create or achieve, might be called a Functional Society, because in such a society the main subject of social emphasis would be the performance of functions. But such a society does not exist, even as a remote ideal, in the modern world, though something like it has hung, an unrealized theory, before men's minds in the past. Modern societies aim at protecting economic rights, while leaving economic functions, except in moments of abnormal emergency, to fulfill themselves" (Tawney, 1920, 28 f.). Polanyi later called the model of an acquisitive society ignorance of the reality of society: "It was an illusion to assume a society shaped by man's will and wish alone. Yet this was the result of a market view of society which equated economics with contractual relationships, and contractual relations with freedom. [...] Any decent individual could imagine himself free from all responsibility for acts of compulsion on the part of a state which he, personally, rejected; or for economic suffering in society from which he, personally, had not benefited. He was 'paying his way, ' was 'in nobody's debt,' and was unentangled in the evil of power and economic value. His lack of responsibility for them seemed so evident that he denied their reality in the name of his freedom" (Polanyi, 2001a, 266). Polanyi exposed this as a convenient illusion.

${ }^{6}$ Polanyi wrote in the "Author's Acknowledgments": Its main thesis was developed during the academic year 1939-40 in conjunction with his work in Tutorial Classes, organized by the Workers' Educational Association, at Morley College, London, at Canterbury, and at Bexhill" (Polanyi, 2001b, xl).
} 
community press for change in society, the judgement passed upon society is inexorable. And when history points to the next step in the achievement of universal community, its claim to the allegiance of the Christian is unconditional" (Polanyi, n.d., 3). The aim has to be a "democracy of freedom" (Polanyi, n.d., 16), which simultaneously preserves the institutions of a complex society and subordinates them to the free life of its citizen in solidarity.

In the already cited 1937/38 Notes from the Training Weekends of the Christian Left, we find some remarkable utterances: "There is no contracting out of society. But where the limits of the socially possible are reached, community unfolds to us its transcending reality. It is to this realm of community beyond society that man yearns to travel" (Polanyi, 1937, 16). Even in his last letter written, shortly before his death on 23 April 1964, to Rudolf Schlesinger, the editor of Co-Existence, the journal he founded, Polanyi stresses again the importance of community and writes: "The essential connotation [to 'nation'] is always about the communion of humans. The heart of the feudal nation was the privilege; the heart of the bourgeois nation was property; the heart of the socialist nation is the people, where collective existence is the enjoyment of a community culture. I myself have never lived in such a society." (quoted in Polanyi-Levitt, 1990, 263)

The interrelationships between the realm of universal community, the habitation and uniqueness of the individual, and his or her freedom with responsibility, together with the irreducible complexity of society as well as, finally, democracy as a mode of life and way of shaping society are key concepts in Polanyi's work and form the matrix of his understanding of socialism. ${ }^{7}$

\section{Three ways to deal with the contradiction between the complexity of society and hu- man freedom}

In 1831, Goethe, during his final efforts to finish his famous Faust after almost 60 years, created a tragic metaphor for modernity. Impressed by the new wave of European revolutions starting in 1830 and reading the works of the French socialist Saint-Simonists (see Jaeger, 2014, $421 \mathrm{ff}$.), he wrote the concluding parts of his work. Faust - a murderer again, blinded by the ghost of anxiousness, commanding a large-scale project of land reclamation in the new industrial age, unaware of the proletarians as the diggers of his grave under the supervision of the devil - exclaims in this last moments of his life: "A swamp lies there below the hill,/ Infecting everything I've done:/ My last and greatest act of will/ Succeeds when that foul pool is gone./ Let me make room for many a million,/ Not wholly secure, but free to work on./ Green fertile fields, where men and herds/ May gain swift comfort

\footnotetext{
7 We can only go briefly into his specific view of 1920 s and 1930 s Soviet socialism. Like many of his left-wing contemporaries he blinded himself to the extent of Stalinism's destruction of civilisation. He also refused to acknowledge the gap between his understanding of socialism and Soviet-type socialism, which along with democratic space had also destroyed the bases of individual freedom (for remarkable perspicacity at a very early date see Luxemburg, 2004; in this connection see Arendt, 1993, 39 f.; for my own position Brie, 2014a). His relationship to socialism was mainly shaped by the non-communist left and by Central and Western European experiences. For him, "Bolshevism" was a subform of socialism alongside others. In this way he missed what was specific to the Soviet system of rule. In the 1930s he wrote that "Russian socialism is still in the dictatorial phase, although a development in the direction of democracy has already become clearly visible" (Polanyi, 1979, 124). In 1939 he said "The working class must stand by Russia for the sake of socialism. Both parts of the sentence are of equal importance. To stand for socialism and not for Russia is the betrayal of socialism in its sole existing embodiment. To stand for Russia without mentioning socialism would also be the betrayal of socialism, which alone makes Russia worth fighting for" (quoted from Karl Polanyi's 1939 manuscript "Russia and the Crisis"' by Nagy, 1994, 99). In 1943 he cited "the French Revolution, the American Revolution, the Russian Revolution, and socialist Britain" within a list of Rousseau's legacy (Polanyi, 2005a, 310), and after 1944 he saw the problems of Soviet socialism in the fact that on the one hand the Russian Revolution "centers rather on the practice of co-operation and the ideal of human fraternity than on liberty and equality" and, on the other hand, that "the Russians are moreover in a different phase of their revolution, [...] far from having reached final fruition" (Polanyi, 1944, 6-7).
} 
from the new-made earth./ Quickly settled in those hills' embrace,/ Piled high by a brave, industrious race./ And in the centre here, a Paradise.../ I wish to gaze again on such a land,/ Free earth: where a free race, in freedom, stand./ Then, to the Moment I'd dare say:/ 'Stay a while! You are so lovely!'" (Goethe, 1832) The greatest vision ever in the midst of destruction and death!

Modernity has many faces and its extremes are the radicalized market-society, the totalitarian rule under the auspices of ideologies, the rational bureaucratic command, and the state-less war of militarized clans in anomic societies. Simple solutions to the complex problems of complex modern societies proved to be traps and nightmares, literally creating not paradise but hell on earth, destroying the freedom it promised to secure. This was true for Bolshevist communism as it was and is true for market liberalism.

Nancy Fraser rightly points out that it is completely wrong to hope for a pendulum swing of the so-called double movement away from market radicalism and toward social protection and to work for it. For this protection can take on authoritarian, repressive, and even barbaric forms under the domination of capital oligarchies or with their active participation. Elements of various sorts of neofascism have been emerging for a long time now. The global surveillance of the communication of citizens is only one such element. The new border regime, drone-based warfare, the massive erosion of social civil rights, and above all the emptying out of democratic institutions are threatening. This kind of 'protection' is the flipside of precisely those tendencies of an unleashed market radicalism against which Polanyi was arguing. The continuation of a double movement is the attempt to stabilize capitalism on its own basis. The decisive strategic task of a transformatively oriented left would be to challenge the foundation of the so-called double movement - the capitalist market society. This in turn overlaps with the goal of "non-reformist reform policies" of the kind that Nancy Fraser asks for (Fraser, 2003, 79 f.). Socially and ecologically oriented entry projects towards a Green New Deal would meld together with entry projects into a solidarity economy in the broadest sense (Dellheim, 2008), into a reproduction economy, based on solidaristic commoning. ${ }^{8}$

In Polanyi's 1943 The Common Man's Masterplan a series of "entry projects" are cited, which are also invoked at the end of The Great Transformation:

Regulated market means markets with no supplementary markets for labor, land and money. The security is possible in a society wealthy enough to banish want without even raising the question of the motive to work.

The freedom of arbitrary rejection of job to be limited.

The freedom of arbitrary dismissal limited.

The freedom of unlimited profits limited.

The unlimited rights of private ownership limited.

The public spirited forms of enterprise fostered.

The plastic society achieved. The helpless society transcended.

The concept of freedom reformed. Christianity transcended. The philosophy of the common man established (Polanyi, 1943, 2).

Karl Polanyi develops three directions to ensure freedom in a complex society: (1) to take the fictious commodities out of the markets; (2) deglobalization; and (3) democratization of democracy.

\footnotetext{
8 On the concept of entry projects see Klein and Brangsch (Brangsch, 2009; Brie, 2014b; Klein, 2004). In this context the Institute for Critical Social Analysis has studied, among other phenomena, participatory budgets (Brangsch and Brangsch, 2008), energy-democracy initiatives (Müller, 2012), as well as free public transport (Dellheim, 2011; Brie \& Candeias, 2012). Erik Olin Wright's real utopias project has tracked these kinds of projects within a comprehensive concept of socialist transformation (Wright, 2010, 2013).
} 


\section{Taking-out the fictious commodities of the market}

The best known proposal of Karl Polanyi for a radical reform to overcome the market society is the removal of the fictious commodities (labour, nature, money - and one may add: knowledge and culture) from the subordination to the markets. His empirical observations and theoretical considerations of the 1920s and 1930s have proved that the subsumtion of the basic goods of a free life to the markets are self-destructive to the economy, the society, the political democratic system, and the whole civilization. Already in his preparation for a lecture on the Übersichtsproblem (the problem of a transparent society) in the late 1920s he wrote:

For the socialists it is evident: the labour force isn't a commodity... Humans aren't a final product but are standing at the beginning of the ... production process as its creator. They are situated outside of the economy. Likewise this is true for some raw materials...(Polanyi, n.d., 18)

Polanyi studied the different attempts to decommodify labour, nature, and money starting from the early $19^{\text {th }}$ century and the proposals of Robert Owen to regulate the labour day. In the mentioned lecture script he adds ideas which anticipate The Great Tranformation: "If the capitalist utopia ever had been true the world had to be at a standstill in the moment it was forbidden to exploit the labour force longer than a fixed number of hours per day" (Polanyi, n.d., 16). Polanyi demanded that the basic conditions of human security and for development should be secured by regulation: "Not only conditions in the factory, hours of work, and modalities of contract, but the basic wage itself, are determined outside the market..." (Polanyi, 2001b, 259) One should be aware that this would include a deep and profound transformation overcoming the concentration of our societies on wage labour. It would be a care revolution (Chorus, 2013; Madörin, 2006; Winker, 2012, 2015). The spheres of life beyond wage labour should dominate the cycles of life. Frigga Haug is speaking about a four-in-one-approach combining wage labour, care, social and political engagement, and Muße (otium) in a balance (see Haug, 2014).

The ecological question and the deep-rooted globalization of investment and commodity chains are radicalizing Polanyi's ideas concerning land and money even more than before. Not only must the economy be re-embedded into the society and society into a strong civilization but the human civilization itself must be re-embedded into sustainable cycles of life on earth. Polanyi is aware: "The nature of property, of course, undergoes a deep change in consequence of such measures since there is no longer any need to allow incomes from the title of property to grow without bounds, merely in order to ensure employment, production, and the use of resources in society" (Polanyi, 2001b, 260). This implies thinking about the end of the pressure for growth (Daly, 1991; Ax \& Hinterberger, 2013; Klingholz, 2014; Mahnkopf, 2013; Paech, 2011). Polanyi sees the "removal of the control of money from the market" (Polanyi, 2001b, 260) nearly completed at the time he is writing The Great Transformation: "Since the introduction of 'functional finance' in allimportant states, the directing of investments and the regulation of the rate of saving have become government tasks" (ibid.). Neoliberal financial-market capitalism has reversed this tendency (Streeck, 2013). The current multi-dimensional crisis of the capitalist civilization would demand the socialization of a larger part of investment, the euthanasia of the rentier (Keynes, 2003), and deep transformation in all parts of the financial- and tax spheres (Flassbeck, Davidson, Galbraith, Koo, et al., 2013; vgl. u.a. Krugman, 2008; Polanyi-Levitt, 2013; Troost, 2010). Nothing less than a transformation of capitalism going beyond it is on the agenda (Klein, 2013).

The expression "to take the fictious commodities out of the markets" could be misunderstood, because markets will need the input of labour, nature, capital, and knowledge anyway. It may be better to speak about the removal of the reproduction of these 
"commodities" from the dominance of the markets. Their development should be steered by their own logic, the logic of their own spheres - the gaia-sphere with regard to nature, the life-worlds with regard to "labour," the sphere of stable and democratic institutions (the sphere of the social) with regard to money, and the sphere of the cultural with regard to knowledge. Without this the deep civilizational crisis will deepen and the new questions of our time won't be answered (see graph 1) (see Brie, 2014c).

Graph 1: The four questions during the crisis of neoliberal financial-market-capitalism

\begin{tabular}{|c|c|c|c|}
\hline the gaia sphere & $\begin{array}{l}\text { tradable natural } \\
\text { resources }\end{array}$ & \multirow{4}{*}{$\begin{array}{c}\text { bourgeois } \\
\text { society } \\
\text { economy and } \\
\text { society under } \\
\text { the } \\
\text { dominance of } \\
\text { capital } \\
\text { accumulation }\end{array}$} & $\begin{array}{l}\text { the earth as a mining } \\
\text { area and garbage heap }\end{array}$ \\
\hline $\begin{array}{l}\text { sphere of the } \\
\text { communal-individual life } \\
\text { worlds }\end{array}$ & wage labour & & $\begin{array}{l}\text { society of labour and } \\
\text { leisure }\end{array}$ \\
\hline $\begin{array}{l}\text { sphere of the social } \\
\text { institutions }\end{array}$ & capital & & $\begin{array}{c}\text { financial-market } \\
\text { capitalism and capitalist } \\
\text { oligarchy }\end{array}$ \\
\hline $\begin{array}{l}\text { sphere of the public- } \\
\text { cultural }\end{array}$ & $\begin{array}{l}\text { knowledge and } \\
\text { culture as } \\
\text { commodities }\end{array}$ & & $\begin{array}{l}\text { culture as entertainment } \\
\text { and self-presentation }\end{array}$ \\
\hline
\end{tabular}

the new ecological question: What are we allowed to produce and consume in which way

the new social question: how do we want to live

the new democratic and peace question: How do we want to decide on which question?

the new cultural question: What does it mean to be human today?

For Polanyi to take the fictious commodities out of the markets does not mean to abolish the markets, rather to change the whole institutional and social framing of the markets. This faces us with a contradiction which is not elaborated in The Great Transformation: The regulation of labour, nature, money, and knowledge must be done in a way to secure the stability and safe reproduction of the most important goods of freedom in a socially just way and in a way that these fictious commodities can be used for economic and noneconomic purposes without destroying them making constant innovation by the permanent re-combination of these "factors" of production possible (Schumpeter, 1964). The discussions with Mises have shown for Polanyi that markets are necessary "to ensure the freedom of the consumer, to indicate the shifting of demand, to influence producers' income, and to serve as an instrument of accountancy, while ceasing altogether to be an organ of economic self-regulation" (Polanyi, 2001b, 260). But the chances to control the dynamics of the markets are bound to the problem of the spatial dimension of the markets. This leads us to the second direction of transformation - to deglobalization.

\section{Deglobalization and the cooperation of large politico-economic and civilizational spaces}

In contrast to the broad reception of Polanyi's position on the fictious commodities and his proposals to remove them from the dominance of the markets, his ideas concerning the pluralization of politico-economic and civilizational spaces are merely taken into account. However, they are at least as important. His close observations of the central European and southeast European development after the disintegration of the Prussian, Habsburg, Ottoman, and Czarist empires led him to work on concrete proposals for a deeper regionalization in Central Europe (see for an example Polanyi, 2002b). In his sketch for a book to be written immediately after The Great Transformation - The Common Man's Masterplan - he concentrates on this task. The post-war order should be an order of peaceful empires cooperating on a global scale. In the ten theses summarizing his proposals in the draft for the Masterplan the problem of taking-out the fictious commodities 
of the markets is just the last (but not the least). Without first creating the necessary international conditions this step seems impossible, as he saw in the 1920s and 1930s:

"The story of the unresolved problems should drive home the following recognitions:

1. That post war reconstruction is not about "What to do with Germany" but what to do with the unsolved problems of the world. No conceivable treatment of Germany will resolve them

2. That these unsolved problems led to World War I and were only partly resolved by the destruction of the feudal empires of the Hohenzollern, the Habsburg, the Romanov and the Sultan-Khalifs; that the between-wars period was entirely dominated by them, including the rise of Hitlerism, British appeasement, the Russian bogey, the collapse of France, the gay twenties, and the wasted thirties in America.

3. That these unsolved problems centered around the antiquated international system of absolute sovereignties and an automatic gold-standard on the one hand, of a national life based on unregulated economies on the other. Between them they corroded the civilization with unemployment and unrest, deflations, and super-wars.

4. That the Hitlerism crime wave could be successful only because it benefited from these unsolved problems which were bursting the world wide open; in the Hitlerian venture some of the most obstructive features of the old world perished including nuisance sovereignties, the gold standard fetish, as well as chaotic markets. But if Hitlerian barbarism was thus "hitch-hiking on the great transformation," it was only because it could pretend to offer an ultimate solution even though it was that of slavery for all under the heel of the Nordics of the Munich beer garden.

5. That the survival of democratic methods depends upon the measure of their success in tackling the global tasks of the time. If freedom fails (a) to restrict the scope of wars, (b) to secure a medium of exchange between increasingly large areas of the planet, then the war-waging slave empire will triumph and ensure peace and division of labour within its confines of death.

6. That the greatest single step towards division of labour and the enlargement of the peace area is represented by essentially autarch and essentially peaceful empires the co-operation of which is institutionally safeguarded, empires such as the U.S.A., Latin America, Great Britain, the U.S.S.R., and a similarly peaceful federation of a German Central Europe, China, India, and some other regions.

7. That the will to cooperation between the empires must be positive and institutionalized. It is the new form of the peace interest which the $19^{\text {th }}$ century produced, and which we should retain and develop. All but the predatory empires are eligible under the new dispensation. The tame empire is no more a utopia.

8. That the $19^{\text {th }}$ century was peacefully imperialistic since under the gold standard the leading powers insisted on spreading their business pattern to all countries and forced them to accept their institutions, without which trade was then not possible. We should model ourselves on China which is and was based on the tolerance of other people's ways of life.

9. That self-sufficient empires can regulate their economic life in the way that they please and live at peace with others. The helpless method of free trade 
must be superseded by direct responsibility of the governments for economic and financial relations with other governments.

10. That internally we must have regulated markets which remove labour land and money from the scope of anarchy. The inevitable increase in centralization that is involved must be met by the positive will to freedom for all minorities - racial, religious, regional, or otherwise - made effective with a single-mindedness modelled on England's achievement."

(Polanyi, 1943)

After WWII Polanyi observed two different tendencies: On the one hand the (in the end more or less successful) attempt of the U.S. to create a new system of a unified global system as it has existed until 1914 with modified rules and the dollar as the new standard. The dollar itself was linked to gold at the rate of $\$ 35$ per ounce of gold until 1971 . The Bretton Wood agreement again established a rigid system with one dominant power. On the other hand, were proposals like those of John Maynard Keynes much more in favor of a regulation binding all sides to avoid strong inequalities of international trade and strengthening the ability for a more autonomous development. Based on Keynes' ideas Britain proposed a "use-it-or-lose-it" mechanism. This would have forced creditor nations to import goods form the debtors, build factories in these states or donate part of the surplus to them (Cesarano, 2006, $160 \mathrm{ff}$.). In this context Polanyi wrote his profound and important article "Universal capitalism or regional planning?" of 1945 and stressed: "The alternative to reactionary Utopia of Wall Street is the deliberate development of the new instruments and organs of foreign trading and paying, which constitutes the essence of regional planning" (Polanyi, 1945, 89). He hoped that the "new permanent pattern of world affairs" would be "one of regional systems co-existing side by side" (Polanyi, 1945, 87). Such large regional systems could make the global market society history with its destructive tendencies and contribute to overcome the side-products of universal capitalism - "intolerant nationalism, petty sovereignties, and economic non-co-operation" (Polanyi, $1945,88)$, which he had studied in detail with regard to the Balkan states in the 1920s.

Polanyi was convinced that the catastrophe of his time originated in the institutional rigidity ("Gleichschaltung") of the utopia of a global market society (linked to free trade and the gold standard). As far as only a few states or only one of them (the global imperial power) are really sovereign and the many are just quasi-sovereigns this leads to right-wing nationalism and fascism - an experience we are making again in our time. The abolition of the global unified capitalist market order is for Polanyi the precondition for true federations of nation-states: "While under market economy and gold standard the idea of federation was justly deemed a nightmare of centralization and uniformity, the end of market economy may well mean effective cooperation with domestic freedom" (Polanyi, 2001b, 262). Deglobalization and the development of new forms of solidaristic cooperation are two sides of the same coin (Bello, 2005). Only under these conditions individual freedom can be secured and democratic planning and control realized.

\section{Protection of individual freedom by democratic planning and control of the economy - democratizing democracy}

Polanyi's intentions can be summarized in the idea of making the economy and society "compatible" with freedom and democracy. For him, the fundamental lesson of the 1930s is: "The stubbornness with which economic liberals, for a critical decade, had, in the service of deflationary policies, supported authoritarian interventionism, merely resulted in a decisive weakening of the democratic forces which might otherwise have averted the fascist catastrophe" (Polanyi, 2001b, 242). According to his paradigm, in a market society the economic and the social interests, entrepreneurship and labour, international cooperation, 
and national sovereignty are in an antagonistic conflict (see Polanyi, 1979, 2001b, $245 \mathrm{ff}$., 2005a). Authoritarian attempts to defend the globalized market economy and capitalism on the one side and the democratic defense of the interests of the population on the other side (often without taking into account economic stability and competitiveness) had lead to a structural confrontation of economy and democracy against which the political system could not hold for long. Fascism emerged as a result of the crisis of the market society. The reluctance to intervene by planning, regulation and control into the economy made fascism possible. Liberalism committed suicide: "Freedom's utter frustration in fascism is, indeed, the inevitable result of the liberal philosophy, which claims that power and compulsion are evil, that freedom demands their absence from a human community. No such thing is possible; in a complex society this becomes apparent" (Polanyi, 2001b, 265 f.). Karl Polanyi combined his commitment to freedom with the demand to use organized state power in a democratic way to regain control over the economy and to regulate it with the purpose to decrease unfreedom and injustice. From his point of view, liberalism represents freedom as the freedom of the few: "The institutional separation of politics and economics, which proved a deadly danger to the substance of society, almost automatically produced freedom at the cost of justice and security" (Polanyi, 2001b, 263). But it has to be stressed that he is totally aware of those liberal achievements which have to be secured at any price and be made a common good for all. He proposed creating strong institutional guarantees to secure the "right to nonconformity" (Polanyi, 2001b, 263). It would be of utter importance, he wrote, to "create spheres of arbitrary freedom protected by unbreakable rules" (Polanyi, 2001b, 264). This includes the imperative: Personal Freedom "should be upheld at all cost - even that of efficiency in production, economy in consumption or rationality in administration. An industrial society can afford to be free" (Polanyi, $2001 b, 264)$. He demanded the extension of civil and political rights to the sphere of the social: "The list should be headed by the right of the individual to a job under approved conditions" (Polanyi, 2001b, 264). Under these conditions "regulation and control can achieve freedom not only for the few, but for all" (Polanyi, 2001b, 265).

These positions were in accordance with the famous four rights stressed by President Roosevelt in his 1941 State of the Union Address (freedom of speech, freedom of worship, freedom from want, and freedom from fear). In 1944 Roosevelt extended this position in a further address to the people of the United States with the demand to pass a second "bill of rights" (Roosevelt, 1944; Sunstein, 2004). His widow, Eleanor Roosevelt, lead the committee of the UN to present a draft of a UN human rights declaration after WWII. The final declaration included social and cultural rights as well as liberal and political rights (Glendon, 2001). In the 1960s and 1970s, new human right declarations were passed (see for a broader documentation and Marxist analysis Klenner, 1982). All these declarations have created a normative framework in deep contradiction to the global economic, political, and social order (Klein, 1997). A "utopian slope" (Habermas, 2010) emerged. The more recent discussion is concentrating on the assumption that the effective defense of human rights demands a protection of common goods as well, namely the "common goods of humanity" (Boff, 2010; Houtart, 2012; see also Brie, 2012). All this proves that there is still a long way to go to ensure freedom in a complex society faced by most urgent global problems and to realize the vision of Polanyi's Great Transformation.

Polanyi's late works further developed approaches to a plurality of exchange principles already adumbrated in The Great Transformation. The traditional societies, which he investigated, are characterized by reciprocity, redistribution, and a subsistence economy. At the same time, as Polanyi noted, they developed extensive markets, which were subjected to strict control. Despite this, the "safeguards of the rule of law and of the traders' liberty" were impressive. He added: "Similarly, ways were found to reconcile economic planning with the requirements of markets in communities as different as democratic Attica of the 
fifth century B.C. and the preliterate Negro Kingdom of Dahomey in West Africa, more than 2000 years later" (Polanyi, 1977, XII). He rejected the alternative "market society or oppression." For him, planning and regulation could be the condition for freedom. His vision was that of a society with a plurality of property and socialization forms, in which a plurality of protagonists shape their own lives in a self-conscious way on the basis of a free agreement on their goals and means. Today's initiatives, either in the form of a socio-ecologically radicalized neo-Keynesianism or, on the other side, of a libertarian commonism, are preconditions for it. But he stressed the most important condition: democracy!

Democracy is in Polanyi's understanding the only form in which free communality can still exist within a complex society with "aggregates of functional institutions." He thought that democratization would give rise to socialism as an attempt - however incompletely - to "make society a distinctively human relationship of persons" (Polanyi, 2001a, 242). He was aware that the complexity of society always produces unintended consequences, which can never be fully controlled. Full oversight and transparency is impossible. However, a much higher degree of freedom and responsibility for the consequences of one's own actions can be achieved. It is true that new relations of domination and new exclusions constantly emerge: "No society is possible in which power and compulsion are absent, nor a world in which force has no function" (Polanyi, 2001a, 266). But according to the last paragraph of The Great Transformation: "Uncomplaining acceptance of the reality of society gives man indomitable courage and strength to remove all removable injustice and unfreedom. As long as he is true to his task of creating more abundant freedom for all, he need not fear that either power or planning will turn against him and destroy the freedom he is building by their instrumentality. This is the meaning of freedom in a complex society; it gives us all the certainty that we need" (Polanyi, 2001a, 268). Here, as already before in Rosa Luxemburg's thinking, freedom is understood as the merging of socialism and democracy, a goal that is at the same time the way. ${ }^{9}$

The civilisational dimension of Polanyi's vision appears when he writes: "After a century of blind 'improvement' man is restoring his 'habitation'" (Polanyi, 2001a, 257). The horizons this opens up could be denoted by the concepts of landscape, urban community ("polis"), the squares and loci of public communality (the "agora"), and the home. Far too many people remain unaware of the radicality of this task. It is a great, enormously attractive vision, which deserves to live. A great deal of this tomorrow has for a long time danced today, as Dieter Klein has vividly shown (Klein, 2013, 169-202). The philosopher Lothar Kühne formulated this context thus: "In the landscape the individual is not only incorporated into a specific community through the house that is crowned by the landscape; in the landscape he/she also has the incipient spatial form of his/her incorporation into humanity, because the landscape indeed exists because of the house although it is essentially nature and earth. The finiteness of individual life has become negated by/absorbed, in creative everyday life, by the species. [...] Thus the house takes back the values that have been separated out and seigneurially inverted in the church. The house is not seigneurial but is homey and wonderful" (Kühne, 1985, 39). To this end, however, the earth must

\footnotetext{
${ }^{9}$ Taking issue with Lenin and Trotsky, Rosa Luxemburg wrote in the summer of 1918 “...socialist democracy is not something which begins only in the promised land after the foundations of socialist economy are created; it does not comes as some sort of Christmas present for the worthy people who, in the interim, have loyally supported a handful of socialist dictators" (Luxemburg, 2004, 208). She wanted transformation in the sense of "resolute attacks upon the well-entrenched rights and economic relationships of bourgeois society," but "in the manner of applying democracy," "out of the active participation of the masses," "subjected to the control of complete public activity" (Luxemburg, 2004, 308).
} 
become a paradise, which we take care of and cautiously preserve - the old Persian word for garden is pairi-daēza (Turner, 2005, 121). ${ }^{10}$

\section{Graph 2: Sustainable solidarity society of the good life}

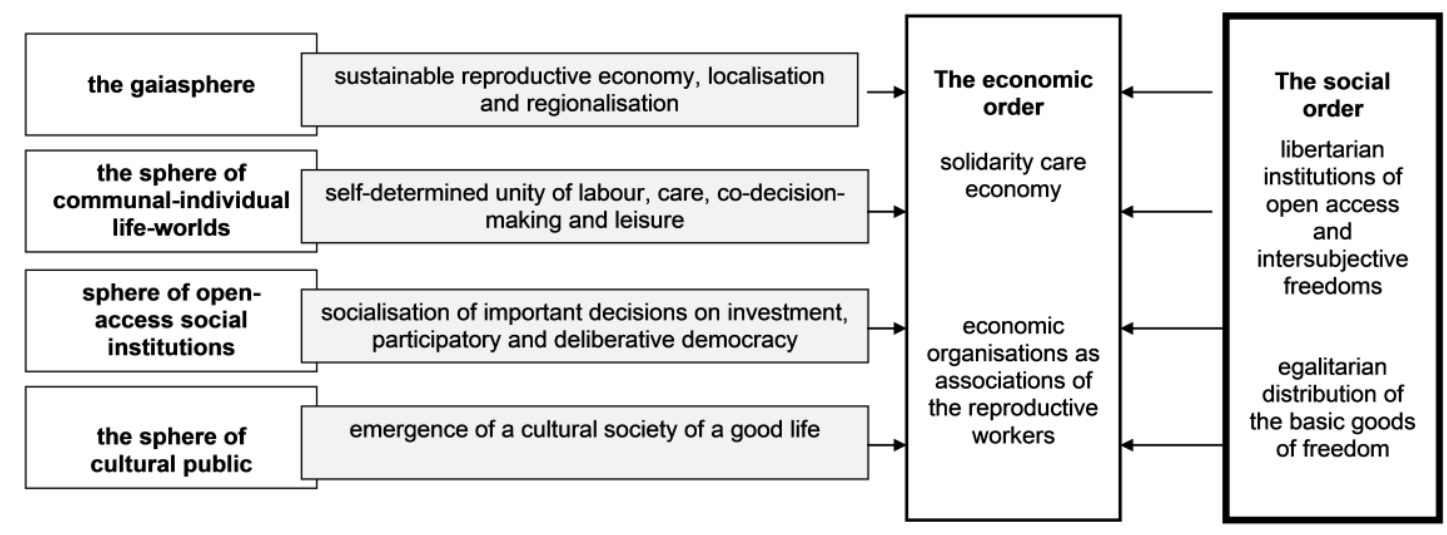

The walls must crumble so that everyone can come and go freely in our cities and communities, no one as an outsider but always as a guest or at home, no one humiliated and no one exalted. Responsibility then can really be taken for freedom; solidaristic communality of provision and care would be a daily matter; citizens would put at least as much time and effort into shaping their social institutions and social life as in the production of goods (for an emancipatory perspective on time see Haug, 2009). In the place of a society whose rhythms and spaces are determined by capital accumulation (Harvey, 2006) the reproduction of solidaristic life would be in accordance to the cycles of life in its very different forms. Traditions of pre-capitalist and modern societies could be combined on a new basis in a "city of being." ${ }^{11}$ A sustainable solidarity society of the good life would arise (Reißig, 2009, $141 \mathrm{ff}$.) (Graph 2). Karl Polanyi's contemporary Ernst Bloch captured this hope in these words: "True genesis is not at the beginning but at the end, and it starts to begin only when society and existence become radical, i.e., grasp their roots. But the root of history is the working, creating [and, we should add, caring - M.B.] human being who reshapes and overhauls the given facts. Once he has grasped himself and re-established what is his, without expropriation and alienation, in real democracy, there arises in the world something which shines into the childhood of all and in which no one has yet been: a homeland" (Bloch, 1995, 1375 f.).

\footnotetext{
${ }^{10}$ In his utopia of a liberated, communist future society, William Morris has a contemporary witness of the great transformation look back and say: "'Yes, [...] the world was being brought to its second birth; how could that take place without a tragedy? [...] The spirit of the new days, of our days, was to be delight in the life of the world; intense and overweening love of the very skin and surface of the earth on which man dwells [...] many of the things which used to be produced - slave-wares for the poor and mere wealth-wasting wares for the rich - ceased to be made"' (Morris, 2004, 119, 121).

${ }^{11}$ This vision was outlined by Erich Fromm who wrote in the conclusion of his work To Have or To Be: "Later Medieval culture flourished because people followed the vision of the City of God. Modern society flourished because people were energized by the vision of the growth of the Earthly City of Progress. In our century, however, this vision deteriorated to that of the Tower of Babel, which is now beginning to collapse and will ultimately bury everybody in its ruins. If the City of God and the Earthly City were thesis and antithesis, a new synthesis is the only alternative to chaos: the synthesis between the spiritual core of the Late Medieval world and the development of rational thought and science since the Renaissance. This synthesis is The City of Being" (Fromm, 2008, 164).
} 


\section{References}

Arendt, H. (1993). Was ist Politik? Fragmente aus dem Nachlass. München: Piper.

Ax, C. \& Hinterberger, F. (2013). Wachstumswahn. Was uns in die Krise führt - und wie wir wieder herauskommen. München: Ludwig.

Bauer, O. (1976). Der Weg zum Sozialismus (1919). In Werke, Bd. 2 (89-131). Wien: Europaverlag.

Bello, W. (2005). De-Globalisierung: Widerstand gegen die neue Weltordnung. Hamburg: VSA.

Bloch, E. (1995). The principle of hope, Vol. 3. Cambridge, Mass.: The MIT Press.

Bockman, J. (2013). Markets in the name of socialism. The left-wing origins of neoliberalism. Stanford: Stanford University Press.

Boff, L. (2010). The rights of Mother Earth. Other News. http://www.othernews.info/2010/03/the-rights-of-mother-earth/ (Accessed October 7, 2014).

Brangsch, L. (2009). „Der Unterschied liegt nicht im Was, wohl aber im Wie“. Einstiegsprojekte als Problem von Zielen und Mitteln linker Bewegungen. In M. Brie (Ed.), Radikale Realpolitik. Plädoyer für eine andere Politik (39-51). Berlin: Karl Dietz Verlag. http://www.rosalux.de/fileadmin/rls_uploads/pdfs/Texte-62.pdf.

Brangsch, P. \& Brangsch, L. (2008). Weshalb? Wieso? Warum? Argumente für den Bürgerhaushalt. Berlin: kommunalpolitisches forum (berlin).

Brie, M. (2012). Making the common good of humanity concrete - For a life in solidarity. In B. Daiber \& F. Houtart (Eds.), A Post-capitalist Paradigm. The Common Good of Humanity (133-158). Brüssel: Büro der Rosa-Luxemburg-Stiftung. rosalux.de/fileadmin/rls uploads/pdfs/sonst_publikationen/common-goood.pdf.

Brie, M. (2014a). Die kommunistischen Opfer kommunistischer Herrschaft. Berliner Debatte Initial, 25(1), 106-110.

Brie, M. (Ed.) (2014b). Futuring. Perspektiven der Transformation im Kapitalismus über ihn hinaus. Münster: Westfälisches Dampfboot.

Brie, M. (2014c). Transformationen des Reichtums - Reichtum der Transformationen. Eine Vier-in-Einem-Perspektive. In M. Brie (Ed.), Futuring. Transformation im Kapitalismus über ihn hinaus (194-241). Münster: Westfälisches Dampfboot.

Brie, M. \& Candeias, M. (2012). Just mobility. Postfossil conversion and free public transport. Berlin: Rosa-Luxemburg-Stiftung. rosalux.de/fileadmin/rls_uploads/pdfs/Analysen/Analyse_Just_Mobility.pdf.

Cangiani, M., Polanyi-Levitt, K. \& Thomasberger, C. (2005). Die Polarität: Menschliche Freiheit - marktwirtschaftliche Institutionen. Zu den Grundlagen von Karl Polanyis Denken. In Chronik der großen Transformation: Artikel und Aufsätze (1920-1945). Bd. 3: Menschliche Freiheit, politische Demokratie und die Auseinandersetzung zwischen Sozialismus und Faschismus (15-64). Marburg: Metropolis. 
Cesarano, F. (2006). Monetary theory and Bretton Woods: The construction of an international monetary order. Cambridge: Cambridge University Press.

Chorus, S. (2013). Care-Ökonomie im Postfordismus - Perspektiven einer integralen Ökonomietheorie. Münster: Westfälisches Dampfboot.

Cole, G. D. H. (1920). Guild socialism re-stated. London: L. Parsons.

Crome, E. (2006). Sozialismus im 21. Jahrhundert. Zwölf Essays über die Zukunft. Berlin: Dietz.

Dale, G. (2010). Karl Polanyi. The limits of the market. Cambridge, UK: Polity.

Daly, H. E. (1991). Steady-state economics. 2nd ed., with new essays. Washington, D.C: Island Press.

Dellheim, J. (2008). Solidarische Ökonomie - ein Thema für sozialistische Politik. Standpunkte, (28). http://www.rosalux.de/fileadmin/rls_uploads/pdfs/Standpunkte_0828.pdf.

Dellheim, J. (2011). Free public and accessible transports. Mehring1. http://ifg.rosalux.de/2011/07/06/free-public-and-accessible-transports/ (Accessed June 20, 2013).

Flassbeck, H., Davidson, P., Galbraith, J.K., Koo, R. et al. (2013). Handelt Jetzt! Das globale Manifest zur Rettung der Wirtschaft. Frankfurt am Main: Westend.

Fraser, N. (2003). Social justice in the age of identity politics: Redistribution, recognition, and participation. In Redistribution or recognition? A political-philosophical exchange (7109). London and New York: Verso.

Fromm, E. (2008). To have or to be?. London and New York: Bloomsbury Academic.

Glendon, M.A. (2001). A world made new: Eleanor Roosevelt and the Universal Declaration of Human Rights. New York: Random House.

Goethe, J. W. v. (1832). Faust - Part II Act V. http://www.poetryintranslation.com/PITBR/German/FaustlIActV.htm\#Act_V_Scene_VII (Accessed September 8, 2015).

Habermas, J. (2010). Das utopische Gefälle. Das Konzept der Menschenwürde und die realistische Utopie der Menschenrechte. Blätter für deutsche und internationale Politik, (8), 43-53.

Harvey, D. (2006). Spaces of neoliberalization. Towards a theory of uneven geographical development. Heidelberg: University of Heidelberg.

Haug, F. (2014). Die Transformation muss am Herrschaftsknoten ansetzen. In M. Brie (Ed.), Futuring. Transformation im Kapitalismus über ihn hinaus (178-219). Münster: Westfälisches Dampfboot.

Haug, F. (2009). Die Vier-in-einem-Perspektive. Politik von Frauen für eine neue Linke. 
Hamburg: Argument.

Houtart, F. (2012). From 'Common Goods' to the 'Common Good of Humanity.' In B. Daiber \& F. Houtart (Eds.), A Post-capitalist Paradigm. The Common Good of Humanity (11-56). Brüssel: Büro der Rosa-Luxemburg-Stiftung. rosalux.de/fileadmin/rls_uploads/pdfs/sonst_publikationen/common-goood.pdf.

Jaeger, M. (2014). Wanderers Verstummen, Goethes Schweigen, Fausts Tragödie. Oder: Die Große Transformation. Würzburg: Königshausen \& Neumann.

Keynes, J. M. (2003). The general theory of employment, interest and money. Australia: Project Gutenberg of Australia eBooks.

Klein, D. (2013). Das Morgen tanzt im Heute. Transformation im Kapitalismus und über ihn hinaus. Hamburg: VSA. http://www.rosalux.de/fileadmin/rls_uploads/pdfs/sonst_publikationen/VSA_Klein_Das_Morgen.pdf.

Klein, D. (2004). Einstiegsprojekte in einen alternativen Entwicklungspfad. http://www.rosalux.de/fileadmin/rls_uploads/pdfs/KleinBrangsch_Einstiegsprojekte_d.pdf (Accessed October 18, 2013).

Klein, E. (1997). Menschenrechte. Stille Revolution des Völkerrechts und Auswirkungen auf die innerstaatliche Rechtsanwendung. Baden Baden: Nomos.

Klenner, H. (1982). Marxismus und Menschenrechte. Studien zur Rechtsphilosophie. Anhang: Menschenrechtskataloge aus Vergangenheit und Gegenwart. Berlin: Akademie.

Klingholz, R. (2014). Sklaven des Wachstums - die Geschichte einer Befreiung. Frankfurt am Main: Campus Verlag.

Krugman, P. R. (2008). Nach Bush. Das Ende der Neokonservativen und die Stunde der Demokraten. Frankfurt, M.: Campus-Verl.

Kühne, L. (1985). Haus und Landschaft. Zu einem Umriss der kommunistischen Kultur des gesellschaftlichen Raumes. In Haus und Landschaft. Aufsätze, Dresden: Verlag der Kunst.

Lewis, J., Polanyi, K. \& Kitchin, D. K. (1935). Christianity and the social revolution. Freeport: Books for Libraries Press.

Luxemburg, R. (2004). The Russian Revolution. In P. Hudis \& K. B. Anderson (Eds.), The Rosa Luxemburg Reader (281-310). New York: Monthly Review Press.

Macmurray, J. (1961). Persons in relations. London: Faber and Faber. http://www.giffordlectures.org/Browse. asp?PubID=TPPIRE\&Volume=0\&Issue=0\&TOC=True.

Madörin, M. (2006). Plädoyer für eine eigenständige Theorie der Care-Ökonomie. In T. Niechoj \& M. Tullney (Eds.), Geschlechterverhältnisse in der Ökonomie (277-297). Marburg: Metropolis.

Mahnkopf, B. (2013). Peak Everything - Peak Capitalism? Folgen der sozial-ökologischen Krise für die Dynamik des historischen Kapitalismus. Working Paper der DFGKollegforscherInnengruppe Postwachstumsgesellschaften (02/2013). 
Marx, K. (1996). Capital. Volume I. In Marx \& Engels Collected Works, New York: International Publishers.

Marx, K. \& Engels, F. (1976). Manifesto of the Communist Party [1848]. In Marx \& Engels Collected Works (477-519). New York: International Publishers.

Mises, L. v. (1932). Gemeinwirtschaft. Untersuchungen über den Sozialismus. Jena: Gustav Fischer.

Müller, T. (2012). Von Energiekämpfen, Energiewenden und Energiedemokratie. LuXemburg. Gesellschaftsanalyse und linke Praxis, (1), 6-15.

Nagy, E. J. (1994). After brotherhood's Golden Age: Karl and Michael Polanyi. In K. McRobbie (Ed.), Humanity, Society, and Commitment. On Karl Polanyi (81-112). Montréal and New York: Black Rose Books.

Paech, N. (2011). Vom grünen Wachstumsmythos zur Postwachstumsökonomie. In W. Welzer \& K. Wiegandt (Eds.), Perspektiven einer nachhaltigen Entwicklung. Wie sieht die Welt im Jahr 2050 aus? (131-151). Frankfurt am Main: Fischer-Taschenbuch-Verl.

Polanyi, K. (n.d.). Christianity and economic life. http://hdl.handle.net/10694/711.

Polanyi, K. (n.d.). Das Uebersichtsproblem. http://hdl.handle.net/10694/253.

Polanyi, K. (1937). Statements from christian left training week-ends. http://hdl.handle.net/10694/764.

Polanyi, K. (1943). Common man's masterplan (Book Plan Draft) [1943]. http://kpolanyi.scoolaid.net:8080/xmlui/handle/10694/719.

Polanyi, K. (1944). The meaning of parliamentary democracy. http://hdl.handle.net/10694/697.

Polanyi, K. (1945). Universal capitalism or regional planning? The London Quarterly of World Affairs, 10(3), 86-91.

Polanyi, K. (1957). Trade and market in the early empires. Glencoe, III: Free Press.

Polanyi, K. (1966). Dahomey and the slave trade. An analysis of an archaic economy. Seattle: University of Washington Press.

Polanyi, K. (1977). The livelihood of man. New York: Academic Press.

Polanyi, K. (1979). Das Wesen des Faschismus. In Ökonomie und Gesellschaft (91-126). Frankfurt am Main: Suhrkamp.

Polanyi, K. (2001a). The Great Transformation. The political and economic origins of our time. 2nd Beacon Paperback ed. Boston, MA: Beacon Press.

Polanyi, K. (2001b). The Great Transformation: The political and economic origins of our time. Boston: Beacon Press. 
Polanyi, K. (2002a). In M. Cangiani \& C. Thomasberger (Eds.), Chronik der großen Transformation: Artikel und Aufsätze (1920-1945). Bd. 1: Wirtschaftliche Transformation, Gegenbewegungen und der Kampf um die Demokratie. Marburg: Metropolis.

Polanyi, K. (2002b). Zur wirtschaftlichen Neuordnung Europas [1930]. In M. Cangiani \& C. Thomasberger (Eds.), Chronik der großen Transformation: Artikel und Aufsätze (19201945). Bd. 1: Wirtschaftliche Transformation, Gegenbewegungen und der Kampf um die Demokratie (110-119). Marburg: Metropolis.

Polanyi, K. (2003). In M. Cangiani \& C. Thomasberger (Eds.), Chronik der großen Transformation: Artikel und Aufsätze (1920-1945). Bd.2: Die internationale Politik zwischen den beiden Weltkriegen. Marburg: Metropolis.

Polanyi, K. (2005a). Jean Jacques Rousseau, oder ist eine freie Gesellschaft möglich? [1943]. In M. Cangiani, K. Polanyi-Levitt \& C. Thomasberger (Eds.), Chronik der großen Transformation: Artikel und Aufsätze (1920-1945). Bd. 3: Menschliche Freiheit, politische Demokratie und die Auseinandersetzung zwischen Sozialismus und Faschismus (296-311). Marburg: Metropolis.

Polanyi, K. (2005b). Sozialistische Rechnungslegung. In M. Cangiani, K. Polanyi-Levitt \& C. Thomasberger (Eds.), Chronik der großen Transformation: Artikel und Aufsätze (19201945). Bd. 3: Menschliche Freiheit, politische Demokratie und die Auseinandersetzung zwischen Sozialismus und Faschismus (71-113). Marburg: Metropolis.

Polanyi, K. (2005c). Über die Freiheit (1927). In Chronik der großen Transformation: Artikel und Aufsätze (1920-1945). Bd. 3: Menschliche Freiheit, politische Demokratie und die Auseinandersetzung zwischen Sozialismus und Faschismus (137-170). Marburg: Metropolis.

Polanyi-Levitt, K. (1990). Karl Polanyi and co-existence. In K. Polanyi-Levitt (Ed.), The Life and work of Karl Polanyi. A celebration (253-262). Montréal/New York: Black Rose Books.

Polanyi-Levitt, K. (2013). From the Great Transformation to the great financialization: On Karl Polanyi and other essays. London/New York: Zed Books.

Reißig, R. (2009). Gesellschafts-Transformation im 21. Jahrhundert. Ein neues Konzept sozialen Wandels. Wiesbaden: VS Verl. für Sozialwissenschaften.

Roosevelt, F. D. (1944). 1944 State of the Union Address. FDR's second Bill of Rights or economic Bill of Rights speech. http://www.fdrlibrary.marist.edu/archives/stateoftheunion.html.

Ruben, P. (1995). Gemeinschaft und Gesellschaft - erneut betrachtet. Philosophische Schriften-Online-Edition, www.peter-ruben.de.

Ruben, P. (1998). Die kommunistische Antwort auf die soziale Frage. Berliner Debatte Initial, 9(1), 5-18.

Schumpeter, J. A. (1964). Business cycles. A theoretical, historical and statistical analysis of the capitalist process. New York and London: McGraw-Hill Book.

Stein, L. (1959). Geschichte der sozialen Bewegung in Frankreich von 1789 bis auf unsere 
Tage. Bd. 2: Die industrielle Gesellschaft, der Sozialismus und Kommunismus Frankreichs von 1830-1848. Darmstadt: Wissenschaftliche Buchgesellschaft.

Streeck, W. (2013). Gekaufte Zeit. Die vertagte Krise des demokratischen Kapitalismus. Berlin: Suhrkamp Verlag.

Sunstein, C. (2004). The second Bill of Rights. FDR's unfinished revolution - and why we need it more than ever. New York: Basic Books.

Tawney, R. H. (1920). The acquisitive society. New York: Harcourt, Brace and Howe.

Tönnies, F. (1887). Gemeinschaft und Gesellschaft. Leipzig: Fues. http://www.deutschestextarchiv.de/book/show/toennies_gemeinschaft_1887 (Accessed July 18, 2014).

Tönnies, F. (2001). Community and civil society. Cambridge: Cambridge University Press.

Troost, A. (2010). Die Vergesellschaftung der Banken konkret denken. Neues Deutschland: 10.

Turner, T. (2005). Garden history. Philosophy and design, 2000 BC--2000 AD. London/New York: Spon Press.

Winker, G. (2012). Care Revolution. In ABC der Alternativen 2.0. Von Alltagskultur bis Zivilgesellschaft (48-49). Hamburg: VSA Verlag. http://www.vsa-verlag.de/nc/buecher/detail/artikel/abc-der-alternativen-20/ (Accessed April 4, 2013).

Winker, G. (2015). Care Revolution. Schritte in eine solidarische Gesellschaft. Bielefeld: transcript.

Wright, E. O. (2010). Envisioning real utopias. London; New York: Verso.

Wright, E. O. (2013). Transforming capitalism through real utopias. Presidential address. American Sociological Review, 78(1), 1-25. 